\title{
Mental health consumer and carer participation: why we bother
}

TO THE EDITOR: It is becoming increasingly recognised that consumer and carer participation improves both quality and outcomes of health care. ${ }^{1}$ The Children of Parents with Mental Illness (COPMI) national initiative is a health promotion program supporting better mental health outcomes for children whose parents have a mental illness (http://www.copmi.net.au). COPMI produces and provides information and resources to support children and families, as well as their carers, health workers and the wider community. It endeavours to involve consumers, family members and other carers in an authentic, respectful manner in all areas, from strategic planning to evaluation.

To improve COPMI's consumer and carer participation strategy and the advice that it offers to organisations wanting to adopt their own systems for consumer and carer participation, we conducted a survey of mental health service consumers, family members and other carers. The survey design, implementation and analysis was led by a mental health service consumer (J C) and carer (T C) in conjunction with a health professional (LT). We used a convenience sample of an accessible, intact group. All 50 members of a group actively involved in COPMI's consumer and carer participation strategy at the time of the study (June-August 2011) were invited to participate. Of the 20 participants who completed the survey, 10 were mental health consumers and 10 were carers (including spouses, adult children, young carers and a grandparent). The categories for the survey were determined by a literature review and feedback from J C and T C. We gathered information on (i) key motivators for consumers, family members and other carers to become participants in health promotion service planning, development, delivery and evaluation; (ii) barriers to involvement; and (iii) key areas that consumers and carers see as requiring the most change.

In our sample, altruism was the major factor motivating consumers and carers to participate in health promotion planning, implementation and evaluation processes (Box). We also identified a number of barriers to participation, such as lack of time, money and access to health services, and the alienating effect of professional jargon. Where possible, these should be actively addressed, to harness the wealth of lived experience, knowledge and empathy of carers and consumers, and to realise better health quality and outcomes. Finally, we found that carers and consumers believe that family members play a vital role in the treatment of a parent's mental illness and that they should be offered supporting services and information.

\begin{tabular}{|c|c|}
\hline \multicolumn{2}{|l|}{$\begin{array}{l}\text { Consumer and carer participation survey: questions and } \\
\text { responses }(n=20)\end{array}$} \\
\hline \multicolumn{2}{|l|}{$\begin{array}{l}\text { What motivates you to be involved in consumer and carer } \\
\text { participation? }\end{array}$} \\
\hline To improve services and resources & 18 \\
\hline To help others & 18 \\
\hline $\begin{array}{l}\text { Commitment to inclusion and ensuring consumer and carer } \\
\text { voices are heard }\end{array}$ & 18 \\
\hline Being able to give back to services & 5 \\
\hline It's part of my recovery process & 4 \\
\hline \multicolumn{2}{|l|}{ What are the barriers to being involved? } \\
\hline Time & 12 \\
\hline Feeling like an outsider (professionals use jargon) & 10 \\
\hline Money & 9 \\
\hline Location/access & 9 \\
\hline Health (mental or physical) & 9 \\
\hline Confidence & 7 \\
\hline Opportunity & 6 \\
\hline Options for participation are not flexible & 4 \\
\hline Stigma & 3 \\
\hline Anonymity & 0 \\
\hline \multicolumn{2}{|l|}{ What do you want to see changed? } \\
\hline $\begin{array}{l}\text { Family to be seen as vital to treatment of mental illness and } \\
\text { offered services }\end{array}$ & 16 \\
\hline More information for children and young people & 15 \\
\hline Services and resources that are useful for families & 15 \\
\hline More workforce education involving consumers and carers & 14 \\
\hline $\begin{array}{l}\text { A stronger consumer and carer voice in mental health in } \\
\text { general }\end{array}$ & 14 \\
\hline Hope for families & 13 \\
\hline $\begin{array}{l}\text { Professionals to have more confidence to ask about families } \\
\text { and provide services }\end{array}$ & 12 \\
\hline Services/professionals recognising the parent role & 11 \\
\hline
\end{tabular}

Lydia C Trowse Consumer and Carer Participation Officer Joanne $G$ Cook Consumer

Tyson J A Clooney Young Carer

Children of Parents with a Mental IIlness national initiative, Adelaide, SA.

Acknowledgement: The COPMI national initiative is delivered through the Australian Infant, Child, Adolescent and Family Mental Health Association, with funding from the Australian Government Department of Health and Ageing.

Competing interests: No relevant disclosures.

doi: 10.5694/mjaoll.11141

1 Fact sheet no. 1: An introduction to consumer participation [internet]. Melbourne: National Resource Centre for Consumer Participation in Health, 2002. http://pandora.nla.gov.au/pan/37708/20061028-0000/ www.participateinhealth.org.au/ClearingHouse/Docs/nrcfactsheet anintroductionmay2002.pdf (accessed Aug 2011). 